\title{
NOTE ON PROTECTIVE RESEMBLANCE, ETC., IN POST- LARVAL STAGES OF SOME CAPE FISHES.
}

\author{
By J. D. F. Gilchrist, M.A., D.Sc., Ph.D.
}

The eggs and larvae of about thirty species of Cape sea fishes are now known, and several eggs and larvae have been described the origin of which are at present doubtful. A few post-larval stages are known, and some of them exhibit interesting characteristics in the form of adaptation, apparently to tide over the dangerous stage between the larval and the adult life. These have been noted in the case of the stock-fish, the leer-fish and others, but the most striking case of obvious adaptation has been found in those of the needle-fish (Hemirhamphus calabaricus). This fish is one of those which may be designated the warm-water fishes of the Cape, which are found chiefly in the warm waters of the east coast and extend round on the south coast to about Cape Agulhas. Beyond this point, to the west, it is scarce, and has not yet been recorded from the west coast. It appears to frequent the shallow lagoons and tidal rivers, and is often found there in such abundance that it is of some commercial value. The eggs and larval stages of the fish are not known, but the post-larval stages prove to be abundant in the shallow waters at some localities, and cau readily be observed when their peculiar habits are known. These young forms, though small (about an inch in length), are yet so far advanced as to leave no doubt but that they are the young of the needle-fish.

On a recent occasion, while procuring the eggs and young of fish in the lagoon at Knysna, Mr. Henkel, Conservator of Forests, drew my attention to the peculiar behaviour of certain small fish-like animals in the water. They could only be detected if approached cautiously or by remaining perfectly still for some considerable time. They were then seen very plainly as small fish swimming about actively in groups of a dozen or more. The lagoon, or harbour, at Knysna is a large area of water extending inland from the sea for several miles. On the mud-flats and banks of this lagoon are extensive areas on which a dense growth of a weed (Zostera?) occurs. During the summer months fragments of this weed are very abundant in the river, so abundant that, in tow-netting for fish eggs, the net was invariably clogged with it in a short time, and fragments, 
of various lengths, of the weed could usually be seen floating in the water. The explanation of the unexpected appearance of the young fish was soon discovered on closer examination, when, what appeared to be such fragments of weed, suddenly seemed to come to life one after the other, till a number of them resolved themselves into a small swarm of young fish, which swam about actively, and were very obvious, even to a casual observer.

The reversal of the process could be very easily observed, for if any sudden movement was made, and more especially, if the hand-net was passed over the water, the small fish at once became rigid and floated about in any position, apparently in a quite helpless inanimate condition. They then so closely resembled fragments of weed, which also floated about, that they could with difficulty be distinguished from them, even by an observer of the transformation. This similarity was increased by the characteristic colour of these small fish, which was a dark green, very similar to that of most of the fragments of the weed. The weed, when floating, usually retains its original green colour, more or less, and when this becomes lost it sinks to the bottom.

The fish, when they have assumed the rigid condition, are not easily roused from it, and can readily be caught by means of a hand-net when in this state.

There can be little doubt but that this is a case of protective resemblance, by means of which the fish escapes the observation of its enemies. At this stage it is apparently more a surface-feeder, and, being a slow swimmer, is exposed to the attacks of the numerous fish and birds which procure their food at or near the surface of the water. Later on it frequents the deeper water, though still a surface-feeder, and is able to escape its enemies by its increased power of swimming. It loses much of its characteristic green colour and probably its habit of feigning death.

Another example of the way in which young fish may be protected is of quite a different nature, and shows not only a superficial but a structural modification not found in the adult stage. This occurs in the "klip-fishes," which are so abundantly represented in the Cape seas, and which, in the adult stage, show some remarkable adaptation to their surroundings.

The young klipfish are born alive, and are at this time of a clear, glassy transparency. They are at once able to swim about actively in the water, and, unlike their parents, do not remain amongst the rocks and weeds at the bottom of the sea, but swim up easily and at once towards the surface of the water; there they remain, near, or at some little distance from the surface, without any special effort. Adult klipfish are unable to remain floating in the water for any considerable time, and when they cease active swimming movements they sink rapidly to the bottom, the reason being that there is no air-bladder, such as we have in most of the fishes, to act as a float. In the young, however, there is a large and well-developed air-bladder, 
by means of which they can remain swimming about slowly or rapidly, or even remain perfectly still in mid-water, where they procure their food. They are difficult to see, even in a tank in the aquarium, on account of their transparency. They are, however, not quite transparent, as there are a number of very distinct but small black dots on the body over the brain and at the bases of the vertical fins. The significance of these black dots may probably be to further disguise the fish, as the outline of the moving body is thereby broken, attention being drawn to the specks.

The leerfish (Lichia amia) is well protected in its adult stage. It has strong and sharp teeth, by means of which it can cause great damage amongst other fish, such as mullet, on which it lives. It is of a more or less uniform colour, without any apparent modification for concealment. The young, however, have a well-marked colour pattern, so distinct from the adult condition that they have been described under a different name (Porthmeus argenteus). Various stages of these fish from an inch or two in length to about 8 inches show the gradual transition to the adult form. The colour pattern in the young is irregular but well marked, and consists of dark patches and streaks on the body, which is of a greenish colour, the extremities of the dorsal and anal fin being brilliant orange. It cannot very well be regarded as a striking case of protective resemblance, though doubtless it serves to render the body less conspicuous in the shallow and confined waters in which these young stages are found.

The transformation in the colour markings of Lichia amia are well known, and are readily observed in the nettings for fish in estuarine rivers in South Africa. Another instance of such a change is not so well known. It was recently found in the case of a dogfish (Acanthias, sp. n.?). In the adult there is a series of relatively small white spots along each side of the body, but in the young the colour pattern is entirely different. There is a broad band of white colour running along each side of the body. It is not exactly similar in all specimens, and is interrupted at irregular intervals. Isolated white spots occur on the head and above the gill openings; there is a pair in front of the first dorsal and another in front of the second. These pairs are constant. The margins of all the fins, including the upper and under side of the caudal fin, are also marked out in conspicuous white patches. There is no doubt that these are the young of the dogfish referred to, as they have frequently been found in the oviduct of this fish.

The young of the stockfish (Merluccius capensis) has also a well-marked colour pattern, absent in the adult.

Other means besides that of resemblance to surroundings are found amongst post-larval stages of fishes for their effective protection. Thus the post-larval snoek (so well armed, in its adult stage, by its formidable teeth) is protected by well-developed serrated spines on the fins and large spines on the head. 
So marked are some of the modifications for the protection of the postlarval stages of fishes that one may well be led to believe that this is the stage that requires special protection. Out of the millions of young which a single pair of fish produce in their life-time, it only requires two to reproduce the species in order to maintain it at its normal quantity, and it is sometimes believed that the necessary elimination of the surplus takes place in the larval stages; but it is not impossible that the most critical period in the life of a fish is the post-larval, and this, as is evident, has an important practical bearing on the question of artificial propagation. 


\section{$2 \mathrm{BHL}$ Biodiversity Heritage Library}

Gilchrist, J. D. F. 1917. "NOTE ON PROTECTIVE RESEMBLANCE, ETC., IN POST-LARVAL STAGES OF SOME CAPE FISHES." Transactions of the Royal Society of South Africa 6, 205-208. https://doi.org/10.1080/00359191709520181.

View This Item Online: https://www.biodiversitylibrary.org/item/181547

DOI: https://doi.org/10.1080/00359191709520181

Permalink: https://www.biodiversitylibrary.org/partpdf/175572

\section{Holding Institution}

Smithsonian Libraries

\section{Sponsored by}

Biodiversity Heritage Library

\section{Copyright \& Reuse}

Copyright Status: Not in copyright. The BHL knows of no copyright restrictions on this item.

This document was created from content at the Biodiversity Heritage Library, the world's largest open access digital library for biodiversity literature and archives. Visit BHL at https://www.biodiversitylibrary.org. 